\title{
TOD Concept among Architecture Graduates
}

\author{
Lutfi Prayogi ${ }^{1}$ \\ ${ }^{1}$ Department of Architecture, Faculty of Engineering, Universitas Muhammadiyah Jakarta \\ lutfi.prayogi@ftumj.ac.id
}

\begin{abstract}
Transit-oriented development (TOD) is a topic that is currently much discussed by architects. Besides discussed by architects, TOD is also much considered by people of various disciplines, such as urban designer, urban planner, property developer, policy developer, etc. The TOD concept understood by architects may be different from the one understood by people of other disciplines. This article compares the TOD concept followed by (candidates of) architecture graduates with the TOD concept that is discussed by people of different disciplines. This article examines the TOD concept that is understood and applied to the architectural design of three architecture graduate candidates with the state of the art of the TOD concept. The comparison is carried out through direct observation of the architectural designing process of the three candidates and reading of the articles written by the candidates recording and summarizing their designing process and the rationales of their designs. It is found that the candidates are very familiar with the regional physical design aspect of TOD (i.e., land-use, density and street network) but are not very familiar with other elements (i.e., residents' mobility, built environment development staging, and transit and property market and development financing). While the candidates applied TOD principles on land-use, density, and street network in their designs, they did not apply TOD principles on the mentioned other aspects. This article shows the TOD concept as understood by architecture graduates and the understanding's position within the state of the art of the TOD concept; this article may serve as the shared footing for people of various disciplines to plan and design TOD.
\end{abstract}

(C) 2018 IJBESR. All rights reserved.

Keywords: TOD concept, architecture graduates, state of the art

\section{Introduction}

After being defined and introduced by Peter Calthorpe [1] in 1993, the transit-oriented development concept has been much discussed by people of various disciplines related to the built environment, such as architect, urban designer, urban planner, property developer, policy developer, etc. Calthorpe introduced TOD as a type of urban development. Later academicians and practitioners develop the concept into various things, ranging from the kind of built environment to the kind of property development and financing.

In recent years, many architecture students have been exposed to the TOD concept both formally through their school's curriculum or informally through other ways. Architecture students have been trying to understand the TOD concept and applying the idea in their architectural design projects. Their architectural design and their rationales of the design reflect their understanding of the concept.

This article tries to explore the understanding of the TOD concept among three Bachelor of Architecture graduates during their time doing their TOD-related Final Project. The TODrelated Final Projects were their last task before becoming a Bachelor of Architecture graduate. This article also tries to compare the three graduates' understanding of the TOD concept with the TOD concept discussed by people of other disciplines. 


\section{Material and Methods}

Understanding of the transit-oriented development (TOD) concept among three Bachelor of Architecture graduates were gained through direct observation of the three graduates doing their TOD-related Final Project. The direct observation was carried out from the early stages of their project (i.e. researching the TOD literature, understanding the TOD concept and defining TOD principles to be applied in their design) to the last phase of their project (i.e. defending the coherence of their design with the TOD concept they previously defined in a design review session). The direct observation was supported by the reading of the graduates' article recording and summarizing their designing process and the rationales of their designs.

The three observed graduates are Adji Prama Priadmadja, Junaedi and Fauzi Firdaus from Bachelor of Architecture program Universitas Muhammadiyah Jakarta. Priadmadja and Junaedi graduated in 2017 while Firdaus graduated in 2018. Priadmadja [2] had TODrelated Final Project in an area around Stasiun Tangerang, Junaedi [3] had one in an area around Stasiun Cisauk, and Firdaus [4] had one in an area around Stasiun Jakartakota.

The state of the art of the TOD concept as discussed by people of various disciplines was obtained through a literature review. Kinds of literature that were reviewed were books and articles reviewing TOD cases around the world. The state of the art of the TOD concept is deductively concluded from the issues commonly discussed in the reviewed pieces of literature. The works of literature reviewed include "Transit-oriented Development in the United States: Experiences, Challenges, and Prospects" by Cervero, Murphy, Ferrell et. al. [5], "Transforming Cities with Transit: Transit and Land-Use Integration for Sustainable Urban Development" by Suzuki, Cervero and Iuchi [6] and "Financing Transit-oriented Development with Land Values: Adapting
Land Value Capture in Developing Countries" by Suzuki, Murakami, Hong and Tamayose [7]. 25 TOD cases discussed by more than 20 people of various disciplines were reviewed.

Comparison of the graduates' understanding of the TOD concept and the state of the art of the TOD concept was carried out through qualitative and two way-inductive approaches. Contents of the graduates' understanding were checked in the state of the art and vice versa.

\section{Results and Discussions}

\subsection{Regional physical design}

The three graduates [2-4] paid much attention to some regional physical design features that they argue significant in transit-oriented development (TOD). The local physical design features that are paid attention by the three graduates are land-use, building density, and street network. In regards of the land-use zoning, the three graduates' designs feature transit stations at the center of their designed areas, office and commercial spaces closer to transit stations and residential spaces farther from the transit stations. In regards to the building-density zoning, the three designs feature high-density buildings closer to transit stations and low-density buildings farther from transit stations. Figure 1 shows the masterplan of TOD area designed by Junaedi [3], featuring office spaces, commercial spaces and apartments closer to the train station towards the top-right of the figure and single-family landed houses farther from the train station. It should be noted that none of the three graduates provided detailed information on land-use and density rules of their designed areas. They, for instance, did not provide accurate information on floor area ratios (FARs) of their designed areas. 


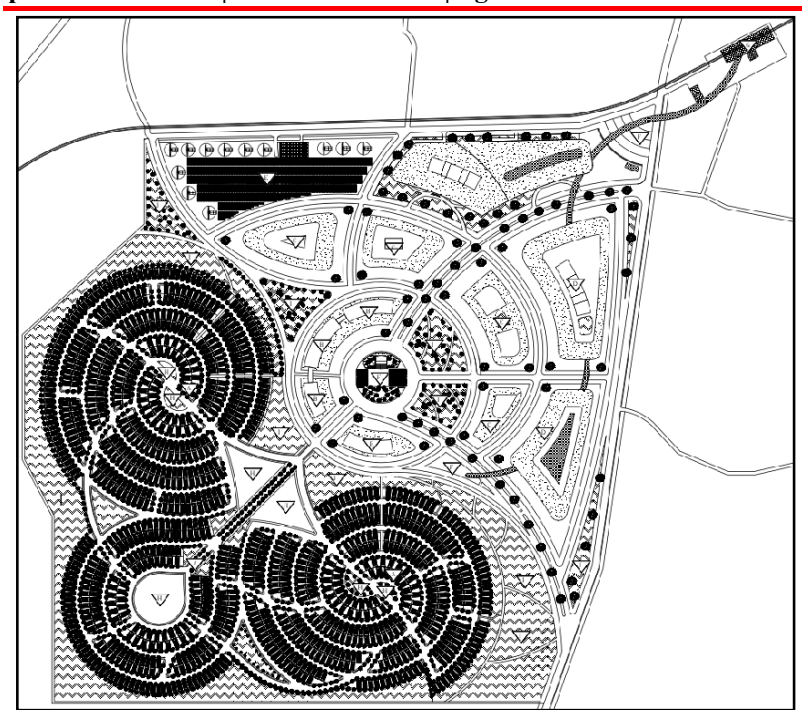

Source: Junaedi, 2017

Figure 1: The masterplan of TOD area designed by Junaedi

In regards to the street pattern, the three graduates' designs feature rather grid-patterned and transit station-oriented street network. Figure 2 shows the existing street network (colored in yellow) and the grid-patterned pedestrian and bicycle-only alleys (colored in red) Firdaus [4] designed.

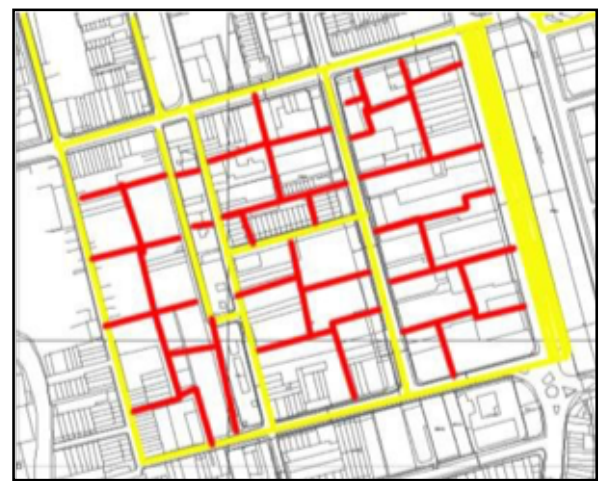

Source: Firdaus, 2018

Figure 2: The existing street network (coloured in yellow) and the grid-patterned pedestrian and bicycleonly alleys (coloured in red) designed by Firdaus

Two of the mentioned regional physical design features (i.e., land-use and building density) are always discussed in the pieces of literature reviewing TOD cases [5-12]. The three mentioned regional physical design features (i.e., land-use, building density, and street network) are highlighted as three TOD principles (i.e., mix, and connect) by ITDP [8]. The three features (land use, building density and street network) are commonly known as 'diversity', 'density' and 'design', in which the three 'D's are commonly acknowledged as considered factors in managing travel demand under the TOD concept $[5,6,8,9,10,11,12]$.

\subsection{Residents' mobility}

In regards to transit, the three graduates [2-4] designed some transit facilities within their areas, including intermodal bus and train station, bus stops, and light-rail stops. Figure 3 shows a section of road accommodating motorized vehicles, bicycles, and pedestrians designed by Junaedi [3].

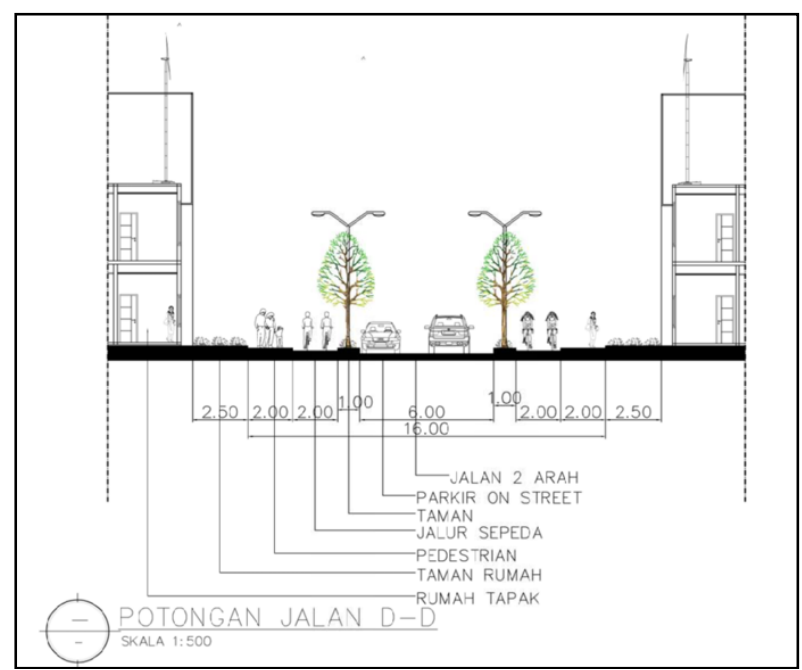

Source: Junaedi, 2017

Figure 3: A section of road accommodating motorized vehicles, bicycles and pedestrians designed by Junaedi

Firdaus [4] paid further attention to the transit use by residents of his area by planning and designing a light-rail line within his area. He considered and tried addressing several issues when planning the light-rail line and stops, including the existing bus rapid transit and rail transit routes, current areas having traffic congestion, existing areas that generate trips and planned areas that will create trips. Furthermore, he meticulously designed the light-rail stops to integrate well with their 
surroundings. Figure 4 shows the light-rail line and stops Firdaus [4] designed, including the areas served by the light-rail stops. Table 1 shows the list of light-rail stops and some important spots/ areas the stops serve.

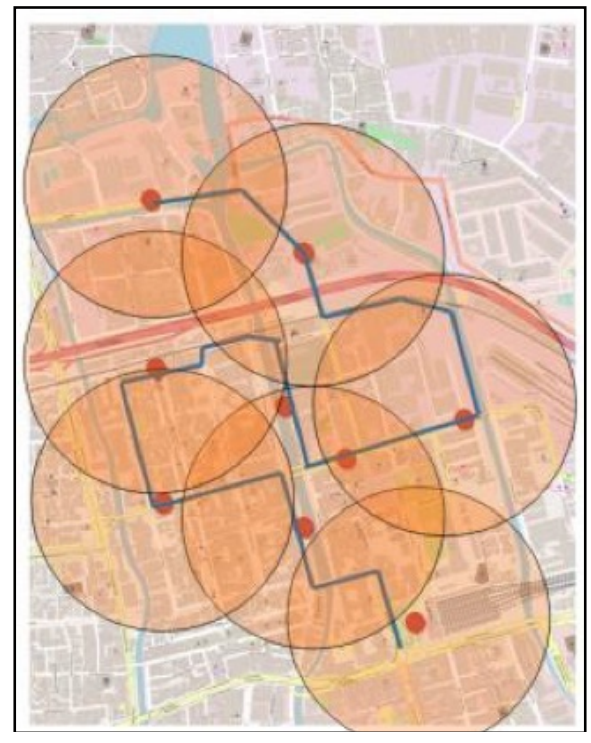

Source: Firdaus, 2018

Figure 4: Light-rail line, stops and areas served by the light-rail stops in the TOD area designed by Firdaus

Table 1: List of light-rail stops and important spots/areas served by the stops

\begin{tabular}{|c|c|}
\hline Stop & Important spots/areas served \\
\hline $\begin{array}{l}\text { Stop } 1 \text { (In front of existing } \\
\text { Jakartakota Station) }\end{array}$ & $\begin{array}{l}\text { Jakartakota Station } \\
\text { Bank Indonesia Museum } \\
\text { Mandiri Museum } \\
\text { Bank Mandiri } \\
\text { Asuransi Jasindo building }\end{array}$ \\
\hline $\begin{array}{l}\text { Stop 2 (Jl. Kali Besar } \\
\text { Barat, } \\
\text { Transjakarta 'Kali Besar' } \\
\text { bus stop) }\end{array}$ & $\begin{array}{l}\text { Puppet Museum (Museum } \\
\text { Wayang) } \\
\text { Toko Merah } \\
\text { Ex Standard Chartered Bank } \\
\text { Kali Besar }\end{array}$ \\
\hline Stop 3 (Jl. Kopi) & $\begin{array}{l}\text { Type-B conserved buildings } \\
\text { with unique façade } \\
\text { Future redevelopment area }\end{array}$ \\
\hline Stop 4 (Jl. Tiang Bendera) & $\begin{array}{l}\text { Interchange station with LRT } \\
\text { Jakarta line Kemayoran- } \\
\text { Bandara Soekarno Hatta } \\
\text { Jembatan Merah } \\
\text { Future redevelopment area }\end{array}$ \\
\hline $\begin{array}{llll}\text { Stop } 5 & \text { (Jl. Kali } & \text { Besar } \\
\text { Timur) } & & & \\
\end{array}$ & $\begin{array}{l}\text { Pemprov DKI-operated } \\
\text { foodcourt } \\
\text { PT Jasa Raharja building }\end{array}$ \\
\hline
\end{tabular}

\begin{tabular}{|c|c|}
\hline & $\begin{array}{l}\text { Jembatan Merah } \\
\text { Kali Krukut }\end{array}$ \\
\hline $\begin{array}{l}\text { Stop } \quad 6 \quad \text { (Existing } \\
\text { Transjakarta } \\
\text { Fatahillah' bus stop) }\end{array}$ & $\begin{array}{l}\text { Fatahillah Museum } \\
\text { Café Batavia } \\
\text { PT Jakarta Lloyd building } \\
\text { Dasaad Musin Concern building } \\
\text { Jakarta Kota Post Office } \\
\text { PT Asuransi Jasindo building } \\
\text { Puppet Museum (Museum } \\
\text { Wayang) }\end{array}$ \\
\hline Stop 7 (Jl. Kunir) & $\begin{array}{l}\text { Geo Wehry \& Co. building } \\
\text { Ceramic Museum } \\
\text { Hotel } 1001\end{array}$ \\
\hline Stop 8 (Jl. Tongkol) & Future development area \\
\hline $\begin{array}{l}\text { Stop } 9 \text { (Jl. Tongkol }-\mathrm{Jl} . \\
\text { Pakin) }\end{array}$ & $\begin{array}{l}\text { VOC shipyard } \\
\text { Syahbandar Tower } \\
\text { Maritime Museum } \\
\text { Sunda Kelapa Port }\end{array}$ \\
\hline
\end{tabular}

Source: Firdaus, 2018, translated by author. Original table in Bahasa Indonesia.

In regards to walking and cycling, the three graduates [2-4] designed some walk and cycle facilities within their areas, including sidewalks and cycle lanes. Firdaus [4] did further by planning and creating roads of various users: roads for pedestrian, cyclist, and driver; and roads for pedestrian and cyclist only. It is worth noting that in regards to driving, the three graduates didn't design facilities for the mobility of private motorized vehicle significantly different from the standard practice in Indonesian cities. For instance, the designed roads have road-space width allocated for motorized vehicle use indifferent from the standard practice.

Residents' mobility is commonly discussed in pieces of literature reviewing TOD cases $[5,6$, $9,10,12]$. Differed from the graduates who paid more attention to the physical design of the transit, walk and cycle facilities, the authors of the reviewed works of literature $[5,6,9,10,12]$ paid more attention to the statistics regarding the residents' mobility. Statistics features that are commonly used when reviewing residents' mobility in TOD areas are mode share and private motorized vehicle ownership. 
Besides, the pieces of literature also reviewed pull and push policies for engineering the residents' mobility. In this case, the physical design of the transit, walk, and cycle facilities is commonly discussed as part of the pull policies making the residents use transit, walk, and cycle more. The physical design of facilities for the mobility of private motorized vehicle is commonly discussed as part of the push policies making the residents drive less [4, $7,13]$.

\subsection{Built environment development staging}

The three graduates [2-4] felled short in acknowledging the stages of the development of the areas they designed. They designed their areas without providing further explanation of how the area will gradually develop. They, specifically, did not provide further explanation on how the area will develop progressively due to the provision of transit services within the area. Neither they offered further clarification on which part of the area need to be developed first (e.g., the transit station, residential spaces, etc.) for the chain of transit-oriented developments to occur in the whole area.

Built environment development staging is a recurring discussion in works of literature reviewing TOD cases $[4,5,8,10,11,12,13]$. The pieces of literature discussed the occurrences of various property developments, both planned and unplanned, after the provision of transit services within an area. The literatures also discussed the chain of developments occurring following the provision of transit services within an area.

\subsection{Transit and property development market and financing}

The three graduates [2-4] provided some information on property development demand within their areas. They predicted the demand for property development within their areas by considering the annual population increase of the areas. However, they felled quite short in acknowledging and predicting the increase of property development demand due to the provision of transit services within their areas.
Furthermore, the three graduates [2-4] also felled short in providing information on the financing strategy of transit and property development within their areas. They, for instance, did not provide any information on the possibility of building transit facilities by utilizing the financial profit of developing residences around the transit stations. Neither they give any information regarding the possibility of operating the transit services by providing residents around the transit stations that serve as potential transit users.

Transit and property development market are commonly discussed in the pieces of literature reviewing TOD cases $[4,6,8,10,11,12]$. The literatures discussed the increase of property development demand due to the provision of transit services within an area. TOD is commonly acknowledged as a type of development addressing such demand increase.

Furthermore, transit and property development financing are a recurring discussion in works of literature reviewing TOD cases $[4,6,8,12,13]$. Some of the literatures promoted integrated transit and property development financing. Some of them encouraged developing property within an area so that the financial profit of the development can be used for building transit facilities and the gained new residents can serve as potential transit users and provide for operating the transit services within the area. Promoted development is commonly known as transit and property joint development $[4,5,6$, $8,12,13]$. The $\mathrm{R}+\mathrm{P}$ (rail plus property) development practiced in Hong Kong is often quoted as an excellent example of such joint development $[5,6,12,13]$. Some of the pieces of literature also promoted a mechanism for financing transit development using the financial gains possibly obtained properties around the transit services. The supported mechanism is commonly known as land value capture $[4,6,12]$. 


\section{Conclusion}

We may conclude from the state of the art of transit-oriented development (TOD) concept that TOD is more than regional/urban physical design. As its name implies, TOD is a type of development, not just a type of regional design. Meanwhile, architecture graduates seemed to understand TOD only as a type of regional design instead of a kind of development. Architecture graduates' understanding of the TOD concept may be induced from their training and tradition of designing space.

We may conclude from the discussions in the previous section that designing an area applying TOD principles on land-use, density, street network complemented with proper transit, walk and cycle facilities is part of designing a TOD. However, planning and creating a TOD also include other things, such as planning the area development staging and financing. Architecture graduates are likely able to design an area applying TOD principles but are unlikely able to plan the development staging and funding for the area. Thus, they are unlikely able to plan and design a TOD comprehensively.

We may assume that people of other disciplines are the complementary opposite of an architect. For instance, property developers are likely able to plan the development staging and financing of a TOD area but are unlikely able to design an area applying TOD principles. Therefore, architects and people of various other disciplines (e.g., urban designer, property developer, etc.) need to work together to plan and design a TOD comprehensively.

\section{References}

[1] Calthorpe P. The Next American Metropolis: Ecology, Community, and the American Dream. $1^{\text {st }}$ ed. New York: Princeton Architectural Press; 1993.

[2] Priadmadja AP, Anisa, Prayogi L. Penerapan konsep transit oriented development (TOD) pada penataan kawasan di Kota Tangerang. Purwarupa 2017;01(02):53-60.

[3] Junaedi, Purwantiasning AW, Prayogi L. Penerapan konsep TOD (transit oriented development) pada perencanaan kawasan permukiman dan komersial yang menggunakan energi terbarukan di Tangerang. Purwarupa 2017;01(02):13-18.

[4] Firdaus F, Purwantiasning AW, Prayogi L. Revitalisasi kawasan Kota Tua Jakarta dengan alternatif konsep TOD. Purwarupa 2018;02(01):35-44.

[5] Cervero R, Murphy S, Ferrell C, et. al. TCRP Report 102: Transit-Oriented Development in the United States: Experiences, Challenges, and Prospects. $1^{\text {st }}$ ed. Washington, DC: Transportation Research Board; 2004. [6] Suzuki H, Cervero R, Iuchi K. Transforming Cities with Transit: Transit and Land-Use Integration for Sustainable Urban Development. $1^{\text {st }}$ ed. Washington, DC: The World Bank; 2013.

[7] Suzuki H, Murakami J, Hong YH, Tamayose B. Financing Transit-Oriented Development with Land Values: Adapting Lang Value Capture in Developing Countries. $1^{\text {st }}$ ed. Washington, DC: The World Bank; 2015.

[8] Institute for Transport and Development Policy. TOD Standard. $2^{\text {nd }}$ ed. New York: Institute for Transport and Development Policy, 2014.

[9] Okata J, Murayama A. Tokyo's urban growth, urban form and sustainability. In Megacities: Urban Form, Governance and Sustainability. Pg. 15-42. Edited by Sorensen A, Okata J. New York: Springer, 2011.

[10] Rode P. Strategic planning for London: Integrating city design and urban transportation. In Megacities: Urban Form, Governance and Sustainability. Pg. 195222. Edited by Sorensen A, Okata J. New York: Springer, 2011.

[11] Yang K, Pojani D. A decade of transit oriented development policies in Brisbane, Australia: Development and land-use impacts. Urban Policy and Research 2017;01:1-16. doi: 10.1080/08111146.2017.1294537

[12] Ratner KA, Goetz AR. The reshaping of land use and urban form in Denver through transit-oriented development. Cities 2013;01:31-46. doi: 10.1016/j.cities.2012.08.007

[13] Loo BPY, Chen C, Chan ETH. Rail-based transitoriented development: Lessons from New York City and Hong Kong. Landscape and Urban Planning 2010;01:202-212.

10.1016/j.landurbplan.2010.06.002

[14] Joshi R, Joseph Y, Patel K, Darji V. Working Paper 38: Transit-Oriented Development: Lessons from International Experiences. Ahmedabad: Centre for Urban Equity, 2017. 